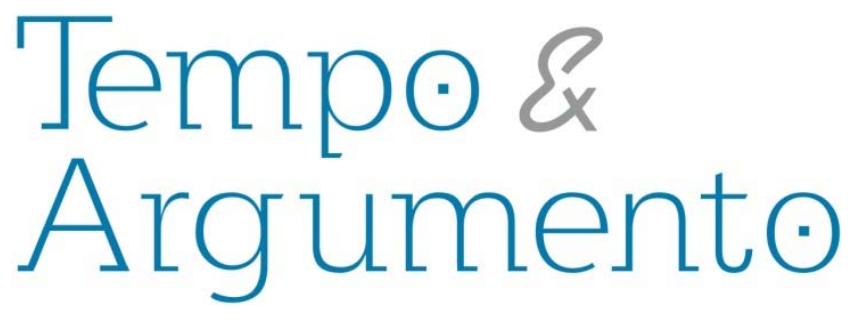

\title{
Artifacts and Artifices among Memory and History ${ }^{1}$
}

\begin{abstract}
This paper intends to discuss ideas, actions, and experiences of people who self-identify as "left-wing" and are also considered by their opponents as the "new left wing", as proposed by a number of scholars to distinguish them from communist groups of traditional formation (Stalinists, Trotskists, etc.). Having been already in operation since the 1950 decade or earlier, with highlights as resistance to the civil-military dictatorship that ruled Brazil between 1964 and 1985, they particularly support the struggle for better conditions of life and work, as well as freedoms in general. Documents produced by these people and found in both public and private spheres have been used to observe this phenomenon. There is particular focus on the joint participation of the left wing movements in trade unions and social movements, as well as in civil society organizations and even institutionally, in frequent clashes with the liberal and populist opposition. The objective is to understand the relevance (or not) of their participation and the possible influences that they may have exerted in the contemporary path that Brazil has taken. Since many of its members were in tune with criticism of the lacking independence of subaltern class mobilizations and organizations, as well as with the importance of fighting for the rights of women and social minorities, they may have given rather unique characteristics to the redemocratization process in the country (1985-1989).
\end{abstract}

Keywords: Memory; History; Dictatorship; Left-wing;

Redemocratization.
Luiz Felipe Falcão, PhD.

Doctor of Social History, Universidade de São Paulo (USP). Associate Professor, Programa de Pós-Graduação em História, Universidade do Estado de Santa Catarina (UDESC).

Brazil

luiz.felipe@mailcity.com

\section{Translator}

\section{Meggie Rosar Fornazari}

Programa de Pós-Graduação em Inglês, Universidade Federal de Santa Catarina (UFSC). Brazil meg.trados@gmail.com

\section{To cite this translation:}

FALCÃO, Luiz Felipe. Artifacts and Artifices among Memory and History. Revista Tempo e Argumento, Florianópolis, v. 7, n. 16, p. 353 - 375. set./dez. 2015. Original title: Artifícios e Artefatos entre Memória e História.

\section{DOI: $\mathbf{1 0 . 5 9 6 5 / 2 1 7 5 1 8 0 3 0 7 1 6 2 0 1 5 3 5 3}$}

http://dx.doi.org/10.5965/2175180307162015353

\footnotetext{
${ }^{1}$ CNPq and FAPESC have granted financial support for the research in this article.
} 


\section{Resumo}

Este artigo pretende discutir ideias, ações e experiências de pessoas identificadas como "de esquerda" por elas mesmas e também por seus oponentes, ou mais precisamente como "nova esquerda", como proposto por vários estudiosos, para distingui-las dos grupos comunistas de formação tradicional (estalinistas, trotskistas, etc.) já atuando nas décadas precedentes, que tiveram destaque na resistência à ditadura civil-militar que governou o Brasil entre 1964 e 1985, em particular apoiando lutas por melhores condições de vida e de trabalho, bem como por liberdades em geral, aproveitando para isto documentos produzidos por elas encontrados em fundos públicos ou privados. Em especial, o texto focaliza a participação destas esquerdas em sindicatos e movimentos sociais, e em organizações da sociedade civil e mesmo em instâncias institucionais, sempre em disputa com as oposições liberais e populistas, com o objetivo de entender a relevância ou não desta participação e, sobretudo, as possíveis influências que exerceram nos rumos assumidos pelo Brasil contemporâneo, uma vez que muitos de seus membros estavam sintonizados com as críticas da falta de independência das mobilizações e organizações das classes subalternas, com a importância da luta das mulheres e das minorias sociais por direitos, o que pode ter emprestado características peculiares ao processo de democratização do país.

Palavras-chave: Memória, História, ditadura, esquerdas, democratização.

I was engaged to this work, if at all, because I refused to allow people and things to vanish without a trace. Could we resign ourselves to this, someday...? (Chien de Printemps, by Patrick Modiano) 
Scholars dedicated to the study of Greek Antiquity (Weinrich, 2001; Yates, 2007) find that the Hellenes believed that Simonides of Ceos was the protagonist of an exemplary situation that defined the secularization of poetry. He was invited to praise in verse the feats of a Thessalonian noble (pugilist, according to Weinrich) named Scopas in one of his feasts. Since Simonides praised the twin heroes Castor and Pollux in a part of his poem, the host refused to pay the full price for the panegyric and told the poet to go to the twins and collect the rest. Among the general mockery that ensued after Scopas' petulance, Simonides was summoned outside the hall by two young men. As he left and could not find them, the hall collapsed upon the revelers and the rubble disfigured them in such a way that the relatives responsible for their funerals could not even recognize them. However, the prodigious memory of the poet remembered perfectly where each person was sitting at the table. This helped identify the revelers and their funeral ceremonies were performed according to tradition.

Although the narrative suggests that Castor and Pollux had saved Simonides as thanks for the respects paid, this narrative carried many other references of the time that are worth mentioning. Firstly, a poem was not the fervent repetition of sacred teachings anymore at that time, but an act of human creation favored by the ingenuity of its author that was paid for this activity and became autonomous from the people in power - upon whom poets depended on until then. Secondly, poets were first- or second-hand eye witnesses of a given event, and thanks to their memory and retelling of events orally conveyed in verse, they were a link between past and future. They masterfully composed their speech to accommodate past, present, and future for the use of teachings or for the mere delight of all. Under these conditions, poems emerged as an artifact and artifice indissolubly merged with memory that - thirdly - by not confusing itself with the events kept itself in opaque and irreducible complicity.

These rather generic considerations on poetry, memory, and orality are useful in connecting the tight nexus between the ability to remember, the potential to express, and human creation itself. In turn, these factors cannot exist in a vacuum, configured as indispensable for another composition genre: historiographical production. Its pretension is to generate in the present an artifact from artifices that can create a relation of 
likelihood with the past, projecting past and present towards possible futures. Thus, an artifact from the present is created with has a lineage connecting it with a past that is not its automatic and immediate origin, with descendants that link it with an unpredictable and uncertain future.

Human creation, with the potential to express and the ability to remember correspond without question to fundamental angles of the historiographical office, or of historiographical work to some extent. For them, History is not confused with procedures and teachings to be prescribed and followed, nor with neutrality and indifference (Febvre, 1985). More than that, History can interfere with the tensions and conflicts that chasm and divide the social fabric, positioning it in a timed dimension and informing the genealogical lineages to which they are connected. From this perspective, this text approaches events, protests, and world-views of Latin American (and particularly Brazilian) recent history that still inspire passionate adherences and resistances. Even though people cannot strictly rule historiographic work, they cannot be completely absent from it if they do not want to run the risk of forgetting "that even the dead are not safe if the enemy wins", and "this enemy has not ceased winning" (Benjamin, 1985).

An analysis of (semi-)clandestine left-wing structures in the re-articulation and reorganization of industry workers, students, and the people against the Brazilian dictatorship implemented in 1964 illustrates this phenomenon. In the ensuing redemocratization period, they continue to clash intensely amidst the construction of memory and the contemporary history of the country. To be more precise, there is still much controversy as to the rise and character of the regime ("hard" or "mild" dictatorship, military dictatorship or civil-military government, coup d'etat or revolution), to the reach of its intervention in the economic modernization and international projection of the country (by attracting capital for investment or making loans to broaden the infrastructure, stabilizing an internal consumer market for durable assets, pursuing Brazilian primacy in the international scenario). Finally, but not less important, there is controversy as to the role of the left wing in standing up and beating the dictatorial regime after defeats in armed confrontation against the regime in urban and 
rural guerrillas ${ }^{2}$. The end of the regime was accompanied by a crescendo in the fight for worker rights in all levels, which include new structures for political organization (Workers' Party or Partido dos Trabalhadores, created in 1980) and union organization (Worker's Central Union or Central Única dos Trabalhadores, created in 1983). They had the support and presence of left-wing organizations, militants, and activists that took directing positions and disputed for the hegemony of its conduction.

In terms of industrial worker and salaried worker mobilization, along with isolated fights in neighborhoods and several companies for very specific reasons, such as salary or working condition improvements in an environment marked by accentuated wage squeeze, prohibitions on strikes, a hard control of unions, and generalized repression against any type of movement. The situation of decrease created by the coup and its recrudescence after 1968 only begun being altered in the second half of the following decade. The students' movement - particularly in São Paulo and with expressive left-wing actions - certainly had been demonstrating the potential for recovery that would lead to the re-establishment of the Student Central Directorate at Universidade de São Paulo (Diretório Central dos Estudantes) in 1976. It was named after Alexandre Vannucchi Leme, a Geology student who was arrested, tortured, and murdered by the repression organizations in 1973. Semi-clandestine left-wing structures such as union oppositions have also certainly furthered the base work in companies, as activists and militants took the opportunities opened by progressive sectors in the Catholic Church - guided by the Liberation Theology $y^{3}$ to give courses and make the social and cultural life of popular neighborhoods more dynamic. However, massive worker protests have only appeared on their living and working places, as well as in unions and in public spaces, a while later.

\footnotetext{
${ }^{2} \mathrm{~A}$ proper reflection upon "the meaning and social roots of left-wing grounds, particularly in armed fights, between 1963 and 1974" can be found in Marcelo Ridenti (2010).

3 The engagement of progressive sectors of the Catholic Church in social struggles throughout the country, particularly in the 1970 and 1980 decades, opened parishes for social movements. This enabled the organization of the people to fight for their claims, elaborating propaganda materials, prophetic and denouncing texts, and so on. From an intellectual standpoint, one of its highlights was the 1975 publication of a collection of studies by renowned researchers from the Brazilian center of analysis and planning (Centro Brasileiro de Análise e Planejamento - CEBRAP) such as Fernando Henrique Cardoso and Lucio Kowarick: São Paulo 1975: Growth and Poverty, produced by request of the São Paulo Archdiocese pontifical committee for justice and peace.
} 
The motivation behind the reappearance of more unified mobilizations had an unexpected incentive: since salaries were submitted to a yearly correction defined by the government, the World Bank published a report in early 1977 that the readjustment would not accompany the 1973 inflation, which was also admitted by some ministers of the president in office, General Ernesto Geisel. An organ that aids union movements, the Brazilian interunion department of socio-economic and statistical studies (Departamento Intersindical de Estatística e Estudos Socioeconômicos - DIEESE) calculated the unpaid difference in $34.1 \%$ and several professional categories started articulating to demand pay for the subtracted values.

In the city of São Bernardo do Campo, the union directors presided by Luiz Inácio "Lula" da Silva created in a first assembly a Mobilization Committee in order to organize the fight for this salary reposition. This committee was comprised of left-wing activists and militants, and distributed a call for another assembly in factory doors and walls as a comic strip starred by João Ferrador. He was a character created to illustrate the union newspaper, Tribuna Metalúrgica, and it nodded towards the possibility of a strike, albeit timidly. The call reverberated broadly, forming an assembly with 3,000 to 5,000 workers the largest in Brazil since 1968 - debating the paths to follow in recovering the withheld values, associated with other sensitive topics of the moment: union autonomy and freedom, free negotiation with patron entities, and the right to strike.

The news spread and the weekly magazine Veja published on September 14th 1977 the cover story "Redemocratization: what about the working class?". This news outlet was in tune with the ruling classes that began drifting apart from the dictatorship due to its "excessive economic interventionism" and "retrograde nationalism", as well as its political antiliberalism that made "redemocratization of the country" more difficult. The story discussed in length the topic of "The factory working class issue" and started as follows.

For the first time in this government, the meetings room on the 5 th floor of the Ministry of Finance in Brasilia opened its doors for a delegation of union leaders of factory workers. This would not be the only victory conquered this week by the São Paulo metallurgy workers, that went to Brasilia to discuss with the ministers of working and economic fields a broad list of topics that are of their interest. In addition, the meeting 
The story contained several interviews with government officials, company leaders, and union directors, including a statement by Romildo Alves Leite, the regional workers' delegate in the state of Pernambuco. In his opinion, unions are comprised of "unprepared rude men", "that spend their money in brothels". Maurício Roscoe, president of the civil construction industry union in the city of Belo Horizonte declared his favor for "an open, democratic government" - complementing that this could only happen "with authority", as "Brazilian workers are not ready for an instrument like the strike, because they wouldn't know how to use it". Otávio Ferreira, president of the textile industry workers' union in the state of Recife, posited that "the fight between bosses and workers is over", because the government "does everything to help us, and gives us everything we ask for", finally remarking that "I don't mean politics - the workers aren't concerned with that."

This set of references in the body of a news story creates artifices that are ingenuously or cunningly mobilized to weave an artifact that can express the editorial opinion of the publishing organ, while at the same time seeking to convince (and obtain consent) of its readership for the ideas they diffuse. Even when the statements of some union directors show reticence or even servility face the governmental authorities, this only evidences the wit in composing a piece that defends the need to "engage salaried workers (...) in a new liberal order". Thus the artifice does not contradict the artifact - that is, the view of the magazine is not blurred, clearly perceiving a change of course with the first worker mobilizations in many years, which leads to a peremptory conclusion:

as to the quality of openness intended for workers, the debate on compensatory adjustment - undeniably, an undigested topic for all arises with many teachings. If union organizations were sufficiently untangled on debating their claims in 1973, upon the miscalculation of inflation, the evil would have been nipped from the bud. The mistake would have been reported and the problem would be timely solved for both parties. 
However, the government refused to review the calculation, claiming that payments had already been done and the companies had not given any room for negotiation. This has made that initial mobilization impracticable, nurturing profound and generalized discontent among workers. The result of this combination of feelings of injustice, frustration, and vexation could not wait. In May 1978, after short shutdowns in some plants, the workers of assembler Scania went into strike, paralyzing the factory on their own account and without any express call from their union. This initiated a surge of strikes in practically every metallurgy plant in the cities of Diadema and São Bernardo do Campo, stimulating similar protests in other cities within São Paulo state. The first steps toward the "new Brazilian trade unionism" had been taken - that is, a confluence of revolt due to low salaries and terrible working conditions, commitment to the base organization, and aspirations to achieve union liberties and full autonomy. ${ }^{4}$ In the following 2 years, two large general strikes mobilized the category under effective union directions to rupture in practice with the legislation that restrained the right to strike, establishing a paradigm of workers' rebelliousness to be followed throughout the country during the 1980 decade.

Within the reach of the Electric Material, Mechanic, and Metallurgical Workers' Union of Diadema and São Bernardo do Campo (henceforth São Bernardo and Diadema Metallurgy Workers' Union), mobilizations spreaded to a given extent and resulted in a sequence of actions initiated by the union. Some examples are the I, II, and III Congresses for Metallurgical Industry Workers of São Bernardo do Campo and Diadema (respectively, in September 1974, September 1976, and October 1978), as well as the I Congress for Metallurgy Women (January 1978), thus evidencing the progressive radicalization of debate and formulations. Luiz Inácio da Silva, their main leadership, had joined the union directors board in 1969 as a fiscal advisor surrogate, receiving an executive position in the

\footnotetext{
${ }^{4}$ It is also important to highlight that on August 27th 1978 the Movement Against Cost of Living was held in Praça da Sé, São Paulo, one of the first protests of the people contesting the dictatorship since 1968. It was organized mostly by poor homemakers from peripheral neighborhoods with the support of the Catholic Church, and protesters were repressed by the Military Police with dogs and bombs, which forced them into the Cathedral for refuge. The movement had collected 1.3 million signatures against expensiveness that were considered forgery by President Geisel.
} 
Furthermore, this inflection counted with the significant participation of militants in clandestine organizations and independent activists from different left-wing currents, although they rarely acted as protagonists in mass mobilizations. ${ }^{5}$ Some examples worth mentioning are: the creation and functioning of an educational center named after Tiradentes (Centro Educacional Tiradentes - CET) between 1974 and 1979, organized by the union to develop Basic Education (for adults) and professional courses; many of its teachers were members of clandestine left-wing structures. In addition, establishing the Department of Culture that gave way to the Ferramenta theatrical group and promoted a course in cinema with Renato Tapajós, ex-Ala Vermelha (a 1960-decade schism in the Brazilian Communist Party with Maoist inspirations - the first organization to formally selfcriticize armed fighting in 1971). This initiated a long-lasting partnership that would result in the production of several documentaries sponsored by the union. Lastly, the establishment of $A B C D^{*}$ News led by Júlio de Grammont, who was also a former Ala Vermelha militant. This newspaper started to officially represent the union directors when it suffered governmental intervention during the 1979 and 1980 strikes (Primo, 1997; Paranhos, 2002; Freire, 2006).

However, the fact that this "new trade unionism" was received by the left-wings conjugated surprise, enchantment, and distrust. The surprise arisen from crescent signs of how worn out was the dictatorship and its repressive legislation, as well as a slow retaking of massive protest movements for better liberties and life conditions. There were clear evidences that the regime had a protuberant capacity for resistance, reinforced by company fears and liberal leaderships face the possibility of working classes and popular layers to join movements. For this reason, the tendency was to stimulate

\footnotetext{
${ }^{5}$ It is worth noticing that (semi-)clandestine left-wing structures played a large role of leadership in other metallurgy worker union bases and, particularly, in professional categories such as banking, journalism, and public school teaching.

* Translator's Note: "ABCD" is a common expression used to describe some cities closest to São Paulo in alphabetical order, namely Santo André, São Bernardo, São Caetano, and Diadema.
} 
pacts with the least intransigent sectors of the dictatorship.In turn, the fights of salaried workers confronted sequels of several years unmobilized. In addition, they underwent a generational renovation, that followed the important transformations through which Brazil passed and the sharing of experiences was thus very limited. The feeling of enchantment arose from strikes and protests with tens and hundreds of thousands of people that were the stuff of dreams. Most left-wing militants and activists had never witnessed such mobilization. New improvements included changes from what predominated before 1964 , such as the fragile base organization, and the accentuated verticalization and centralization of union entities.

Finally, the feeling of distrust departed from the left wings face the "new trade unionism", particularly among the metallurgy workers in São Bernardo do Campo and Diadema, that certainly involved a number of issues. Firstly, was this a trade unionism that rose within a bureaucratic union structure with strong connections with the Federal State, creating a unique combination of combative movements and pragmatic accommodations in the ruling order. ${ }^{6}$ For example, a union document accounting for the activities of a committee of associates and directors in assembly on August 141977 in order to mobilize the category for their $34.1 \%$ postulated in its Item 8 to create "support factory groups, to propagate the fight and mobilize the category...", while in Item 10 it explained "The feasibility of a strike movement must not be overlooked, as long as it is under Bill \#4,330 and that the category is prepared for it."7 That is, they explicitly

\footnotetext{
${ }^{6}$ The challenge of understanding this "new trade unionism" was not limited to left-wing (semi-)clandestine structures, as proven by the polemic interpretations it had in academic spheres. Maria Hermínia Tavares de Almeida (1996) believes that there was some sort of "working-class aristocracy" similar to the US trade unionism (combative, rooted in the workplace, and well prepared to defend workers' interests) and for this reason it tended toward some degree of accommodation in the ruling social order. In turn, Ricardo Antunes (1995) gives more focus to elaborating a ranking of strike movements, considering mobilizations in São Bernardo as spontaneous - as they may have not been directed towards the political dimension that they ultimately achieved. However, there is some consensus in the sense that the "new trade unionism" was not successful with some of its premises. The autonomous organization in companies and a rupture with the official union structure, be it due to its settling on benefits (such as the union tax paid by companies to the State that was later distributed to the unions) or due to its weaknesses. For example, the Metallurgy Union Opposition of São Paulo, the most prominent and influent in the country, was never successful in its disputes to direct the union. In addition, employers managed to suppress company commissions formed at the height of mobilizations. An elucidatory balance of this academic debate can be read in Naiara Dal Molin (2013).

7 Several documents in Archive 72, Political Parties and Organizations, Box n.3, single documents, Edgard Leuenroth Archive, Universidade Estadual de Campinas (UNICAMP).
} 
decide upon the legality of their claims. Moreover, when the union suffered governmental interventions in the first general strike convened by its board of directors in 1979, Lula's initial reaction was to go home, certain that the situation was now irreversible and that he would return to his position in the factory to retake the lead of the movement a few days later.

Secondly, such distrust could be equally explained by the very distrust of the "new trade unionism" members against certain practices from some left-wing lines of action that were seen as adventurous and avant-garde, not respecing the objective conditions of the political moment and the state of maturity in workers. One example was the growing tension that emerged after the May 1978 strikes between the directors of the São Bernardo and Diadema Metallurgy Workers' Union and the teachers in their school, the aforementioned CET. They criticized the direction and their performance in mobilizations publicly and within school grounds, to their students. This culminated into the irrevocable decision of the board to close the school indefinitely (Paranhos, 2002, p. 129, 143, and 160). As recalled years later by Devanir Ribeiro, one of the directors:

These teachers had a more ideological and less practical standpoint. Everyone was against us - not only them, but the Workers' Pastoral, too. They didn't understand it back then, but they did later on - how capital and work transform (...) Every director sitting on a table with their employee was betraying the working class. (...) If Lula appeared on Globo $T V$, good gracious, the next day he'd be screwed: 'you can't, that's bourgeois'. (Primo, 1997, p. 102) ${ }^{8}$

\footnotetext{
${ }^{8}$ An illustration of the dissonating union leaders and some clandestine left-wing structures came from the political working-class Marxist and Leninist combat organization (Organização de Combate Marxista Leninista Política Operária, or OCML-PO). This was a derivate of the Political working-class Marxist revolutionary organization (Organização Revolucionária Marxista Política Operária, or ORM-PO), the first group of the Brazilian "new left wing", established in 1961. OCML-PO released in 1976 a defense for a $45 \%$ inflation as guarantee of fight against the "political ground" squeeze, since other indexes "address only a fight for economic resistance". 1976 was a year that preceded any possibilities of less disperse and isolated mobilizations of the working class, with salary reposition at $200 \%$ (which self-criticized the previously proposed $110 \% . .$. ). Citations from clandestine newspaper Política Operária 46 (no cover, likely from June-July 1976, p. 8, Archive 72, Political Parties and Organizations, Box n.2, single documents, Edgard Leuenroth Archive, Universidade Estadual de Campinas (UNICAMP). A scathing assessment of Política Operária by one of its historic directors, Raul Villa (a pseudonym for Eder Sader) appeared in
} 
The noticeable differences between union directors and militants in clandestine left-wing structures working at CET was seen by directors as a contrast between ideology and practice or pragmatism. Specifically in the case of teachers that were also members of the Trotskian group named Internationalist Socialist Organization that edited the newspaper $O$ Trabalho and maintained this editing position. Other agents would also be involved in this last case, such as the Working Pastoral of the Catholic Church, in direct criticism to the São Paulo Metallurgy Union Opposition, in which Christian left-wing workers exerted great leadership and influence, without hiding their reserves face dubious or conciliatory attitudes of the São Bernardo and Diadema Metallurgy Workers' Union directors. The São Paulo Metallurgy Union Opposition was a central political union front that joined in the category with importance in the late 1970 decade, when they led a long and broad strike, as well as throughout the following decade.

Thirdly, such distrust was also linked to the (pre-)conceptions of an orthodox Marxist-Leninist formation of those left wings, according to which they would be the only legitimate bearers of the authentic class consciousness of the proletariat. This made life difficult among unionists, who were gradually growing politically through learning, fighting, and under the intervention of unorthodox left-wing activists that respected greatly the autonomy of social movements and entities. In these particulars, distrust only increased when unionists and activists signaled the importance of establishing a political party to represent them and uphold their standards of fight, which ultimately constituted the Brazilian Workers' Party, or Partido dos Trabalhadores (PT), between the years of 1979 and 1980 (Humphrey, 1982; Sader, 1988).

One example is in a typed text found in the Edgard Leuenroth Archive at UNICAMP, with no date or identification. Its contents leave no doubt that it was written by a worker militant in a clandestine structure of São Bernardo do Campo, criticizing the direction the local metallurgy union took during the $34.1 \%$ mobilization:

In the meantime, after the second assembly, the union directors - who were, until then, taking all propositions and participating on referrals - 
Another document in the same archive is the even more scathing text entitled "The so-called Workers' Party and the interests of the working class", with no date or indication of authorship. It is dedicated to fighting the proposal to establish the party, claiming that the growth of workers' fight led the bourgeois to "allow - and even support - the emergence of more representative union leaderships" and to "stimulate the creation of new parties acting withing the rules established within the limits allowed by the bourgeois parliament, presenting more attractive proposals for the working class", in order to "prevent workers from getting organized independently within their workplaces (...)" (5 and 6). After calling Lula an "authentic leader", the author compares the Brazilian and English workers' party, as well as with socialist parties in Spain and Portugal, in order to defend the formation of an authentically revolutionary party (9 and 10), wrapping the rationale thusly: "All of this shows that the Workers' Party has very little to do with the working class. It is impossible that any alliance, attempt of conciliation, or even taking advantages of loopholes for the party to act further on the left..." (10).

However, such positioning was not unanimous among the left wings, as demonstrated by the aforementioned examples of the $A B C D$ News or documentaries filmed by Renato Tapajós. To reinforce this argument, one may mention guidelines formulated by the national directors of one of the most active clandestine left-wing structures at the time. The movement for emancipation of the proletariat (Movimento pela Emancipação do Proletariado - $\mathrm{MEP}^{9}$ ) published these guidelines in their official organ, Nova Luta, in a September 1978 editorial ${ }^{10}$. The author gives credit to strike movements throughout the country for the repercussions of a political and economical crisis that created a sense of discontent and a longing for change, while highlighting the

\footnotetext{
${ }_{9}$ A left-wing organization emerged from a schism within POLOP, active in Brazil in the 1970 and 1980 decades.

${ }^{10}$ I thank Carlos Henrique Menegozzo for mentioning the existence of this rich archive.

** Translator's Note: the "pelego" in Brazilian Portuguese is the last usable part of sheep, the pelt that goes under riding saddles. In Brazilian politics, the term pelego started being used in the 1930 decade as a person trusted by the government to lead unions, guaranteeing its connections to the Federal State - a term to designate those who betray workers in alliances with their bosses and the government.
} 

to later affirm that there was a kind of "wide front" formed within unions in favor of union autonomy and liberties, the right to strike, and company commissions, based on what defined its attitude face this "new trade unionism":

(...) From this "wide front" we can highlight two areas that are more generic. One is more combative; some participants are Lula, Olívio, Porto Alegre bankers, the president (sic) of the metallurgy workers unions of Santos, "Tanker" Ronaldo, João Paulo of Monlevade, and others. The other wing has the traditional pelegos** that will to some extent take opposition stances on their claims, as in the case of Marcílio in Santo André, and Enos in Osasco. The hard fact is that the first wing has been particularly performing a more active role in the fight against the pelego trade unionism. (...) Due to its current practice, we must consider them as allies in the fight against the pelego trade unionism, although they are contradictory and feeble.

During the crisis, among growing discontent and strike surges, the union directors adopted two divergent stances. One that was "more combative", expropriating opposition flags without any greater restrictions: union autonomy and liberties, the right to strike and have base organization in companies. The other was less inclined to the activism imposed by the moment, but also incorporated little by little the claims of oppositions and distanced itself from the traditionally accommodated and police-like pelego style. Face this scenario, militants and sympathizers should not falter in considering the first group as "allies in the fight against the pelego trade unionism" even though they acknowledged behaviors that often "faltered in contradiction", according to the newspaper.

The editorial complements the text with reference to this diagnostic:

Today, this current led by Lula and others represents a current of opposition. (...) while these currents create conditions to further the fight against the pelegos and bureaucratic unions, it is our role to be there so the minimum program of opposition is put into practice, taking as many opportunities as possible in unions led by these oppositions to increase our strength and our leadership. (...) 
After a long period of severe repression, without large massive protest movements or broadly and deeply inserted among workers, the difficulty authors found in characterizing with precision the environment they faced is quite noticeable. Their starting point was a conjuncture that changed rapidly with nearly no connection with any previous experience. No artifice can sculpt an artifact such as what Veja magazine made from a liberal perspective towards the country "redemocratization" - that is, a parameter to return the institutional order under the hegemony of the economically and politically ruling classes. For the left wings and particularly for MEP, the challenge was more complex as its influence was not substantial even with the "new trade unionism". Not even Lula, who composed a "current of opposition" against the "bureaucratic unions", even assuming an "attitude of opposition" with "falterings" that are pointed out, but never dissected. As a result, it would be a "mistake" or even political suicide to form union oppositions in which these directors are ahead of union entities. Instead, they should act with them to implement the "minimum program of opposition".

This is even more evident in a document entitled "Discussing tactics in a broad workers' meeting (a contribution to the debate)" likely of mid-1978 and signed by the regional committee of this group in São Paulo. ${ }^{11}$ Here, the explicit concern appears to be in securing political cohesion face tensions that seem to have emerged with the scenario created by the strike movements, as well as with the decision of supporting the "combative candidates" under the Brazilian democratic movement (Movimento Democrático Brasileiro - MDB). This was an opposition party allowed by the dictatorship to sustain a facade of institutional normality. To this end, the discourse of workers in this meeting is reproduced in detail, in order to guarantee an effect of exemplarity to be followed by the militants, whether they are salaried workers or not.

\footnotetext{
${ }^{11}$ Archive 72, Political Parties and Organizations, Box n.2, Edgard Leuenroth Archive, Universidade Estadual de Campinas (UNICAMP).
} 
The text begins coherent with such intention, mentioning support to the organization: "we must love MEP" or "I first adhered to parties at MEP", followed by mild censorship to the fact that its political line would have been formulated "without a more democratic process of debate and decision-making" (2). In sequence, the author allows the understanding of what lied in the tactical document. There was a crisis in the dictatorship regime, aggravated by an economic crisis that was not caused by mass movements, but mostly due to the end of the period of accelerated economic growth (the "miracle"12), as well as by inter-bourgeois disputes that ensued. There were three main forces at play in this scenario. One would be represented by the governmental proposal to gradually distend the dictatorship, captained by the President in office, General Ernesto Geisel, and his most notorious advisor, General Golbery do Couto e Silva. A second force was comprised of liberals in the national front for redemocratization, which brought together General Euler Bentes Monteiro, the MDB, ARENA (the official government party) and segments of the national renovator alliance (Aliança Renovadora Nacional). Lastly, the third force was formed by "social-democracy" - that is, old populist leaders, new union leaders, and segments of the MDB (3).

Based on these analyses, the document then reproduces speeches of workers present in the meeting. In a first moment, this is done to assess factory strikes started in São Bernardo do Campo that later spreaded on to other areas and categories:

Strikes on the $A B C$ occurred spontaneously or with combative unionists within a few factories, which was the case of Scania... but in my region the Union Opposition went one step beyond, trying to spark the strike and the $20 \%$ index by printing pamphlets for each factory, and managing to get several strikes with that. In this sense, many strikes were spontaneous, but there was a higher degree of organization and mobilization in those where the Union Opposition was present. (4)

Or:

In my region we discuss with some comrades of other trends. They are stubborn in claiming that no fight is possible without organization in factories or the formation of factory committees. Well, then; they have seen a few factories go into strike without a single element of the opposition. There are some other comrades that claimed that the masses were not ready, that the climate was not heated up and stuff like that,

\footnotetext{
${ }^{12}$ Cordeiro (2015) brings a proper analysis of the "miracle" and its implications in terms of popular consent obtained then by the dictatorial regime.
} 
Another place counting with a union direction considered as "opposition", apparently in São Bernardo do Campo:

Over there on my region there's no formed opinion; there's people from the opposition appearing in the assemblies and doing their job. Although ... is combative, he boycotts the presence of left-wing people in several moments. (...) in an assembly, people from the opposition proposed an Amnesty Committee in the region. That proposal passed, ... didn't forward it, emptied the proposal creating a Human Rights Defense Committee, and even capitalized it for himself. Over there, it's easier for the union to drag the left wing around than for the lefties to take advantage of the loopholes. (10: the name of the union director does not appear on the text)

By adopting a procedure that reminds us of Simonides of Ceos in his recalling to identify the dead in the baneful banquet, although in this document it was not important to remember where each person was sitting, no matter how unimportant they were. This document, possibly elaborated from records or audio recordings, the author(s) of the text showed clear intentions of inducing a performance by recalling in high detail their words, reflections, and feelings. Objective conditions were favorable to the deflagration of strikes, even if restricted to economic claims such as better salaries and working conditions, or gaining political dimension as they clashed against the legislation that prohibited them. Responsibility would fall to the combative union directors, union oppositions, and "avant-garde" workers to seize the moment and make the organization and mobilizations prosper towards the formation of a political consciousness.

However, the great dilemma was the lack of consensus among members of these combative union directors, union oppositions, and left-wing militants. Several aspects had not reached a consensus, neither objective conditions favorable for broader strike 
leadership with more combative union directors, it was left to left-wing worker militants to acknowledge that it was "easier for the union to drag the left wing that for the left wing to take advantage of the loopholes created". This is coherent with a document typed by a militant left-wing metallurgy worker with no title or date, apparently from the same period and the same party organization to be distributed to other workers and explain the scenario, convoking workers for the fight. At a certain point, one reads that:

[The union directors] are the same that have coffee with the workers and diss the bosses. They're the same people that sit with us and make an impression. Then right after, the excitement they created themselves cools off just because Labor Justice denied to meet our demands. How hard and sensitive it is to work at a Union with this kind of director board. But still, we endure...

It was proven that the current union directors are like "ballroom girls". They just soften the rugs in small gatherings, social work, appealing and kissing the asses of bosses and government... $(2 \text { and } 3)^{13}$

The attempt to collect ambiguities within conducts taken by the union directors initially combative directors that disappointed their members. This can be quite evidenced between the lines of the text. It is a board of directors that has coffee with workers and "disses" their bosses - that is, that makes a positive impression - to later fall back before the authorities when they refuse to accept their proposed demands, as the "excitement they created themselves cools off". For this reason, the author completes the rationale by comparing the directors to "ballroom girls", softening the rugs they step on during the parties promoted by the entity and agenting social work activities, as well as in meetings with bosses and government members. How may one characterize precisely such a board of directors? How may one guarantee that it grows politically while remaining faithful to what a clandestine left-wing structure militant learned to consider as the authentic interests of the working class as a whole? Or in turn, how may one challenge and surpass the leadership it sports? In fact, the daily struggle is "hard,

\footnotetext{
${ }^{13}$ Archive 72, Political Parties and Organizations, Box n.3, Edgard Leuenroth Archive, Universidade Estadual de Campinas (UNICAMP).
} 
reanimation of workers' fight for better salaries, life and work conditions, and liberties within the context of a gradual disaggregation from the dictatorship. For those insisting in an orthodox appropriation of Leninism, paradoxes grew as the construction of legal structures of politics and unionism advanced and consolidated, such as PT and CUT, as expressions of the working class movement. On the one hand, the emergence of these legal structures was received enthusiastically by several (semi-)clandestine left-wing structures, as well as by deriving activists and collectives. Some examples are the aforementioned Ala Vermelha and MEP, as well as the Leninist Marist popular action (Ação Popular Marista Leninista - APML). This allowed a rupture from social isolation, particularly amidst the working class environment that had suffered bitter defeats in nearly every front of action. On the other hand, the notorious heterogeneity of these legal structures carried the obligation of competing against powerful forces in their direction and put a strain on the designation of how indispensable it was to form a revolutionary party. Some left-wing trends were led to treat these structures as relatively loose fronts that allowed them to make alliances with groups in other environments, such as the students' movement. These groups stigmatized the Workers' Party as a representative of social peace and reform - that is, a social-democrat party of the worst kind, as (dis)qualified by João Amazonas, main director of PCdoB $(1981,10) .{ }^{14}$

The sinuous movement observable in the document produced by the left wings of that time is understandable and even inevitable in these terms. Their options were often made incongruent with the objectives they sought in short, mid, and long terms. This was only made stronger in the 1982 elections, the first participation of PT. In spite of the enormous expectations and empathy it awakened, the performance was awful. This

\footnotetext{
${ }^{14}$ PCdoB was not alone in this judgment, as proven by the document entitled "The 'Workers' Party' and the interests of the working class" (Archive 72, Political Parties and Organizations, Box n.2, Edgard Leuenroth Archive) without date or signature - but likely by a Trotskian group in 1980, which states that "...PT has very little to do with the working class. Any form of alliance is impossible. Any attempt of conciliation or even to 'take advantage of a Workers' Party loophole to act further left', as much often used to justify its actions on and towards MDB, has only contributed to connect the working class to the bourgeois." (10)
} 
unveiled a hiatus between the workers' mobilization and their political consciousness, thus proving the powerlessness of the party to introduce itself as an alternative for Brazil in a context of economic crisis and putrefaction of the dictatorship. An internal dispute over the paths to be taken ensued. As several leaderships sustained in a series of debates over the party's conjuncture and possible destinies, this legal structure ran the double risk of being socially isolated in case it opted for a program of indoctrination and co-opting to join the ruling social order in case it chose to settle within the ruling institutions particularly within parliaments. ${ }^{15}$

To sum up, legal structures such as PT and CUT corresponded to unprecedented articulations in the country. They put together union leaderships prestigious among workers and popular movements with intellectuals, students, artists, professionals, and parts of progressive churches (particularly from sectors of the Catholic Church influenced by the Liberation Theology). Some of them were organized left-wing activists or militants ${ }^{16}$. In this sense, they were artifacts in formation in a context of renovation for social agents, as well as acute tensions, clashes, and imbalances. Artifacts which were unfinished and permeable to various artifices interested in shaping them according to different conveniences, by counting with a significant participation of the left wings. This could perhaps be done due to the fact that these left wings occupied places not then duly identified, saturated with the history and memory of Brazilian social struggles in the latest decades of the 2oth century as well as the first decades of the 21st.

15 "PT e o momento atual", a series of 5 volumes reproducing the debates occurred at Fundação Wilson Pinheiro between April 30th and May 28th 1983, was published in July that same year. This foundation was created by PT for cultural advisory, and its archive belongs to Fundação Perseu Abramo in São Paulo. Secco (2011) presents a history of PT.

${ }^{16}$ In this context, contact with Brazilian exiles influenced greatly upon an entire critical literature of MarxistLeninist orthodoxy. Some examples are works produced by Corneliius Castoriadis and Claude Lefort in France, or by Edward Palmer Thompson in Great Britain, as well as a complete re-reading of Antonio Gramsci's work. This occurred even with some productions from the so-called "Eurocommunism" - a movement emerged in some European communist parties in Spain, France, and Italy - in the sense of incorporating references such as democracy, hegemony, and political plurality in its political proposals and practices. All of this development occurred during as growing distrusts in relation to the Soviet Union and other regimes of what Rudolf Bahro (1982) called the "De-Facto Existing Socialism" largely influenced the left-wing rationale in Brazil during the process of disaggregation of dictatorship and redemocratization. However, a deeper treatment of this context exceeds the objectives and scope of this article. 


\section{References}

\section{Archive references (clandestine typed, mimeographed, or printed means)}

Acervo 72, Organizações e Partidos Políticos, caixas 1 a 5, pertencente ao Arquivo Edgard Leuenroth da Universidade Estadual de Campinas (UNICAMP).

Nova Luta (órgão do Movimento pela Emancipação do Proletariado), várias edições, acervo de periódicos pertencente ao Centro de Documentação e Memória (CEDEM) da Universidade Estadual Paulista (UNESP), São Paulo.

O PT e o momento atual (5 cadernos). São Paulo: Fundação Wilson Pinheiro, 1983, acervo pertencente à Fundação Perseu Abramo, São Paulo.

\section{Printed references:}

ALMEIDA, Maria Herminia Tavares. Crise econômica e interesses organizados: o sindicalismo no Brasil nos anos 80. São Paulo: EDUSP,1996.

AMAZONAS, João. A socialdemocracia, instrumento do capitalismo, Revista Princípios, no. 2, São Paulo: Editora Anita Garibaldi, junho de 1981, p. 3-10.

ANTUNES, Ricardo. O novo sindicalismo no Brasil. Campinas: Pontes, 1995.

BAHRO, Rudolf. Crítica ao socialismo realmente existente. São Paulo: Brasiliense, 1982.

BENJAMIIN, Walter. Sobre o conceito de História. In: BENJAMIN, Walter. Obras escolhidas: vol. 1: magia e técnica, arte e política. São Paulo: Brasiliense, 1985.

CORDEIRO, Janaina Martins. A ditadura em tempos de milagre: comemorações, orgulho e consentimento. Rio de Janeiro: FGV, 2015.

DAL MOLIN, Naiara. Sindicato e Estado no Brasil: o sindicalismo no período populista e o Novo Sindicalismo, Pensamento Plural, Pelotas: Programa de Pós-Graduação da Universidade Federal de Pelotas, n.13, p. 89-108, julho/dezembro 2013.

FEBVRE, Lucien. Manifesto dos Anais novos (1946). In: FEBVRE, Lucien. Combates pela história. Lisboa: Presença, 1985. 
FREIRE, Alípio. Organizações e movimentos populares e de trabalhadores na segunda metade dos anos 1970 ou de um tempo quando não havia guias geniais dos povos, In: MAUÊS, Flamarion e ABRAMO, Zilah Wndel (Org.). Pela democracia, contra o arbítrio: a oposição democrática do golpe de 1964 à campanha das Diretas Já. São Paulo: Fundação Perseu Abramo, 2006.

HUMPHREY, John. Controle capitalista e luta operaria na indústria automobilística brasileira: fazendo milagre. Petrópolis: Vozes, 1982.

PARANHOS, Kátia Rodrigues. Mentes que brilham: sindicalismo e práticas culturais dos metalúrgicos de São Bernardo. 2002, Tese (Doutorado em História - Universidade de Campinas, Campinas, 2002.

PRIMO, Antônio Aparecido. O Centro Educacional Tiradentes: Escola do Sindicato dos Metalúrgicos de São Bernardo do Campo e Diadema (1974-1979). 1997, Dissertação (Mestrado em História) - Universidade de São Paulo, São Paulo, 1997.

RIDENTI, Marcelo. O fantasma da revolução brasileira. $2^{\text {a }}$. ed.). São Paulo: UNESP, 2010.

SADER, Eder. Quando novos personagens entraram em cena: experiências, falas e lutas dos trabalhadores da Grande São Paulo, 1970-1980. Rio de Janeiro: Paz e Terra, 1988.

São Paulo 1975: crescimento e pobreza. São Paulo: Loyola, 1976.

SECCO, Lincoln. História do PT . Cotia/SP: Ateliê, 2011.

VEJA, São Paulo, 14 de setembro de 1977.

WEINRICH, Harald. Lete: arte e critica do esquecimento. Rio de Janeiro: Civilização Brasileira, 2001.

YATES, Frances A. A arte da memória. Campinas: UNICAMP, 2007. 
Received in August 15, 2015 Approved in October 10, 2015

Universidade do Estado de Santa Catarina - UDESC

Programa de Pós-Graduação em História - PPGH

Revista Tempo e Argumento Volume 07 - Número 16 - Ano 2015 tempoeargumento@gmail.com 